\title{
ON THE PROBLEM OF ASSESSMENT OF SUSTAINABILITY IN THE SEA SHORE REGION
}

\author{
Kristina Ramanauskaité ${ }^{1}$, Angelija BuČIENË² \\ Klaipeda University (Lithuania)
}

\begin{abstract}
Definitions and sets of indicators as well as approaches on sustainable development are compiled, discussed and evaluated in this paper. The researched region embraces for five urban and district municipalities in western Lithuania and Latvia in the total area of $1393.93 \mathrm{~km}^{2}$. The scheme of steps of assessment of sustainability with selected sets of indicators relevant for the sea shore region of Lithuania and Latvia is presented and discussed.

KEY WORDS: sustainability, assessment, sea shore region.
\end{abstract}

JEL CODES: Q01, Q56.

\section{Introduction}

The sea shore or coastal zone's importance in the country's economics is one of the greatest in most of world countries because of high natural and human resources located there (Berkes et al., 2003; Gadal and Lekavičiūte, 2012; Walter, Stützel, 2009). In the sense of spatial planning, it involves a territory in the sea and on land, the boundaries of which are defined by mutual influences and interests (Pužulis, 2010; Spiriajevas, 2012; Burgis, Čiegis, 2012). According to the research in Finland, about $40 \%$ of Baltic sea shore habitat types are threatened (SH7 Red-listed, 2008). The seashore meadows, seasonally flooded meadows and paludified wet meadows are among the most valuable rural landscapes in the coastal areas. This kind of areas has most certainly decreased lately, due to decreased grazing and hay harvesting, drainage activities, cultivation or increased damp construction with shrinking of agricultural activities. However the tourism, recreation, fishing, sports are increasing and their impact on the environment in these regions increases as well. That is why it is important to develop different human activities in harmony with natural processes in ecosystems. The harmony or balance between components of human-natural systems are included in the term of sustainability, thus we have to focus first on what the meaning is allotted to this term by different researchers in order to group their statements and to reveal the most appropriate steps for the assessment of concrete situation in sea shore region. The complex landuse management or so-called Integrated Coastal Zone Management (ICZM) is one of the practical guidelines how to unite all the sub-systems of this region to one wholeness (Berkes and Folke, 1998; Berkes et al, 2003). But in order to assess the situation and work out different measures for concrete region, still many of research activities have to be done.

\footnotetext{
Kristina Ramanauskaitė - master student of Social geography of Klaipèda University. Scientistic interest: regional sustainability assessment problems

E-mail: ramanauskaitekristina@gmail.com

Tel.: +370 62604550

2 Angelija Bučienè - prof. dr. (Geography), Klaipèda University. Scientistic interests: regional and environmental problems of rural Lithuania and other Baltic sea region countries

E-mail: angelija.buciene@ku.lt

Tel.: +37061582692
} 
The aim of this paper was to discuss and analyze the scientific approaches and methodologies searching the assessment of sustainability development in the Baltic

Sea shore region with focus on western Latvia and Lithuania municipalities. For this, two tasks were conducted: 1. Compilation of scientific literature. 2. Preparation of appropriate scheme/methodics for assessment of sea shore region development sustainability.

The methods of the research include the analysis of scientific literature, the principles of general and logical analysis; the methods of comparison and summary, as well as abstraction. The ArcGis 10.1 programme was applied for preparation of map of the region. The sea shore region in this research is analysed for a whole area of municipality, reaching the Baltic sea. Thus, in Lithuania such municipalities are: Neringa urban, Klaipeda district and Klaipèda urban, Palanga urban and Kretinga district; in Latvia - Liepaja urban and Liepaja district, Ventspils urban and district and Talsi district municipality (Fig. 1).

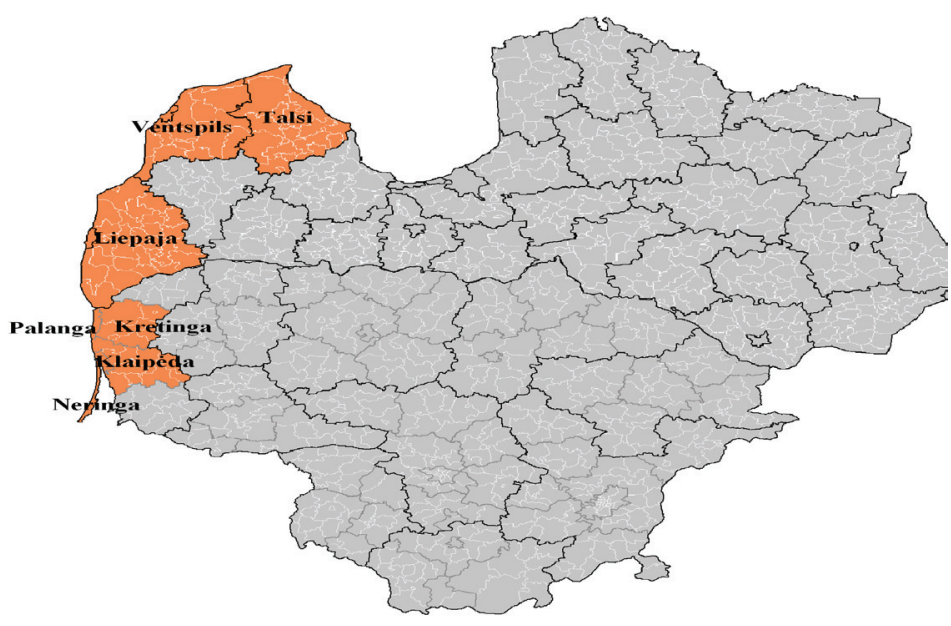

Figure 1. Map of studied Baltic sea shore region area with 8 municipalities

The total researched area of the region made $1269.336 \mathrm{~km}^{2}$ in Lithuania and $124.594 \mathrm{~km}^{2}$ in Latvia. The Baltic coast of Lithuania extends to $91.6 \mathrm{~km}$, and it is one of the shortest national coastlines in Europe. The northern part $(46 \mathrm{~km})$ of the Lithuanian Baltic coast belongs to three municipalities: Klaipeda urban municipality, Klaipeda district municipality and Palanga urban municipality, and the southern part (45.6 km) belongs to Neringa urban municipality and Klaipeda urban municipality as well. The Baltic coast in Latvia is much longer: it stretches ca $496 \mathrm{~km}$ long and $253 \mathrm{~km}$ of which is an open Baltic Sea coast (Lapinskis, 2005). In this paper we analysed not all Latvian coast, but its western part in Kurzeme region within the administration borders of Talsi district municipality in the north-east.

\section{Results and discussion}

\subsection{Natural and human resources and coastal protection policy in the researched region}

Baltic sea shore region is diverse in different landscapes with higher or lower anthropogenic impact. During the last 20 years the eastern Baltic sea coastal region of Lithuania and Latvia has been changed as other regions of these two countries after the collapse of SSSR. First of all changes were caused by the drop of many economic activities in the beginning of transition to market economy period. From another hand, with start of Land reform from 1990-1991, a large number of small farms or homelands appeared with more diverse mosaic of landscape and extensive farming. Later some of them stopped farming because of growing 
concurency and due to the aging of farmers or migration of younger people to the towns or abroad. Thus the area of abandoned agricultural land began to increase in rural territories from early ninethies and this process is continuing even nowadays (Bučienè, 2012; Veteikis et al., 2011). At the same time aforestation in some places took place. The area of protected landscapes and habitats increased as well. The urbanisation process is not typical for the researched coastal region, rather sub-urbanisation is prevailing. This is evident, while analysing the distribution of population in the studied municipalities in 2003 and 2012 (Fig. 2).

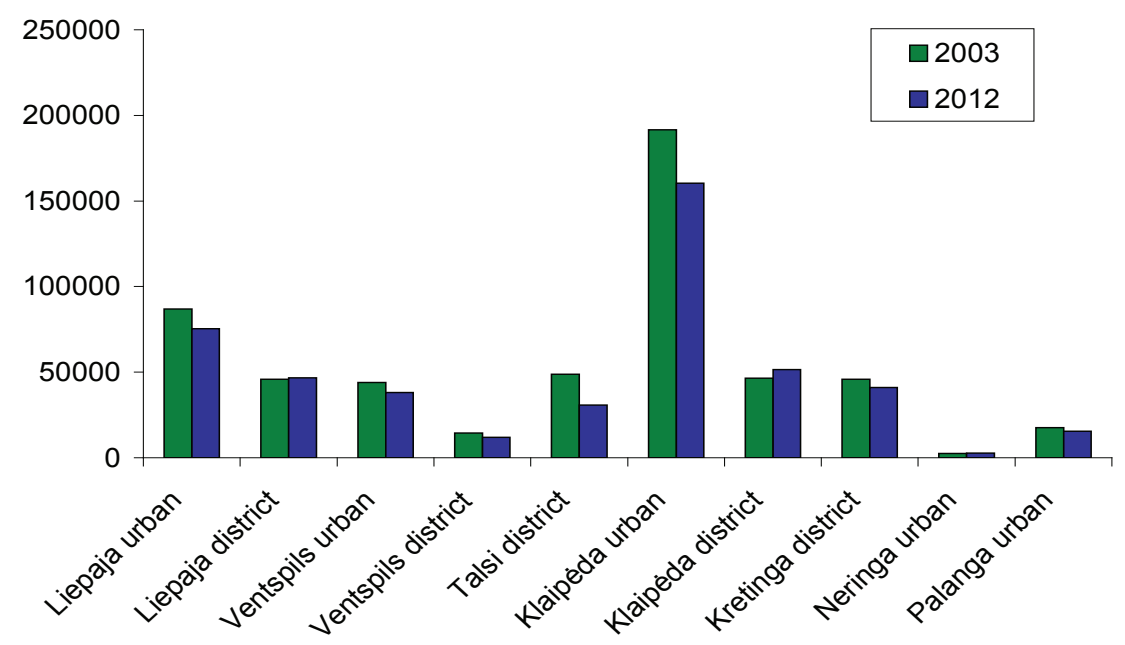

Figure 2. The population number in the municipalities of studied region, 2003-2012.

Sources: www.stat.gov.lt; www.stat.gov.lv

The larger towns like Klaipeda, Liepaja and Ventspils decreased in population number as compared with situation before entering EU, however the small increase was typical to Liepaja district and Klaipeda district municipality mostly due to the process of sub-urbanisation.

Forests occupy about $33 \%$ of Lithuania's and $51.2 \%$ of Latvia's territory. The total growing stock of forests in Latvia amounted to $633 \mathrm{mln} . \mathrm{m}^{3}$ in 2009 (Meža (...), 2010). Mostly conifers - $55 \%$, birch - 30 \%, and grey alder $-7 \%$ dominate in Latvia's forests. Aspen accounts for only $4 \%$ (Meža (...), 2010). The distribution of forests in the country's territory is not even - the regions of Kurzeme and Vidzeme have more forest lands than the regions of Latgale and Zemgale, which can be explained by different growing conditions for forests, different hydrological conditions, and proportions of agricultural land in these regions (Bite, Makovskis, 2011). In Lithuania more forests are typical for the eastern-southern Lithuania and for Curonian Spit in the very west (more $80 \%$ ), while the rest of sea shore region territory is covered little by forests (Lazdinis, 2002; Bučienè, Beržanskis, 2011).

Significant part of coastal zone in Latvia is still almost unexploited and well preserved with occurrence of natural and semi-natural habitats. The coastal dune belt with its nature values is unique not only in Latvia but in the whole Europe scale since it holds important part of the EU and national significance habitats. Ca $60 \%$ of this territory are habitats under protection in the EU and Latvia and $15 \%$ of these habitats are under priority protection.

The most significant legal instrument for protection and management of the coastal zone is a Law on Protected Belts. This Law in Latvia defines a special protection of the Baltic Sea, Riga Gulf and their coastal habitats within the coastline as ca $300 \mathrm{~m}$ wide belt from the coastline towards inland and the shelf zone till $10 \mathrm{~m}$ izobath (Fig. 3a).

The limited economic activities zone in Latvia coast stretches up to $5 \mathrm{~km}$ landwards which is demarcated according to the natural conditions and where many economic activities are restricted or limited (Pužulis, 
2010). Key aspects include the restriction of the expansion of built-up areas, the limitation of forestry activities versus the maintenance of natural and semi-natural landscapes and also the protection of coastal areas against erosion (Veidemane, 2011).

The "Programme for Coastal Zone Management" was confirmed in Lithuania in 2003. It served as a basis for the development and implementation of coastal management projects for 2004-2007. Later a new "Programme of coastal management for 2008-2013" was elaborated and confirmed (Programme (...), 2007). In Lithuania the protected Baltic sea shore zone reaches $3 \mathrm{~km}$ in width from the coast line to the continent, and within sea till the isobath of $20 \mathrm{~m}$ depth (Fig. 3b).

a

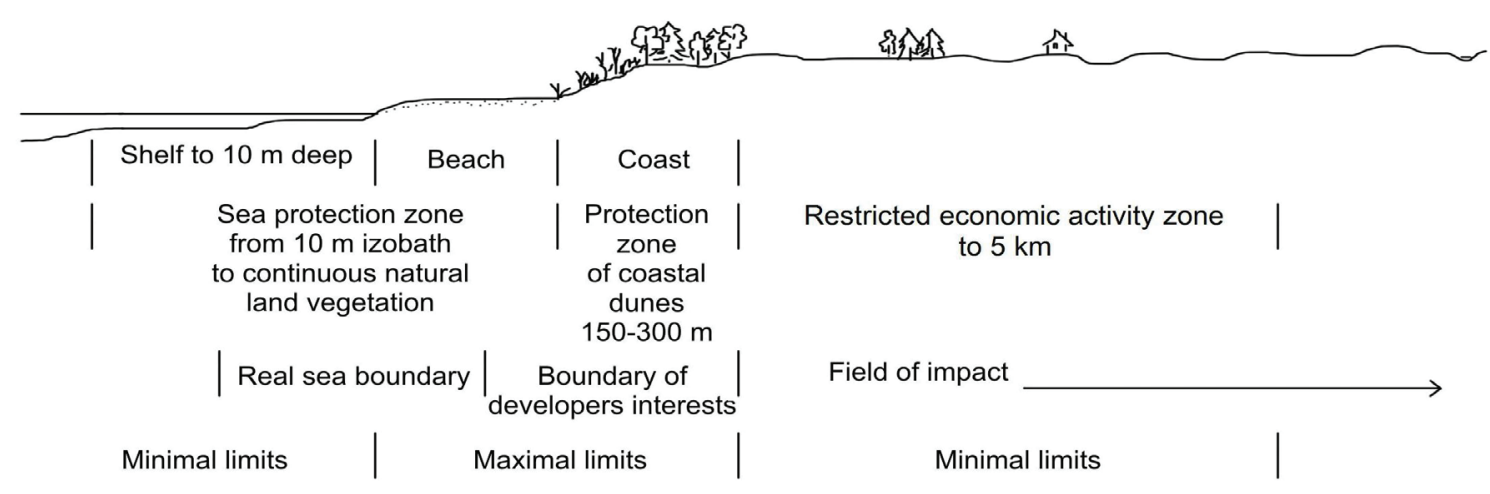

$\mathrm{b}$

| Sea protection zone from $20 \mathrm{~m}$ deph (isobath)

Protected coastal zone to $3 \mathrm{~km}$ (50,

Figure 3. Zoning in the Baltic Sea and Gulf of Riga Coastal Protection Zone in Latvia (a) and in Lithuania (b)

Sources: Pužulis, 2010; Jūros krantų (...), 2000

In the last 30 years (1976-2006), the total length of Lithuanian accumulative coastal sectors has been reducing by about $110 \mathrm{~m}$ every year on the average because of ersion processes. The total length of eroded coastal sectors has been increasing by $367 \mathrm{~m}$ every year on the average. For comparison it should be reminded that during the previous 30 years (1946-1976), the total annual reduction of accumulative coastal sectors was $100 \mathrm{~m}$ on the average, and the increase of the length of eroded sectors was only $33 \mathrm{~m}$ (Jarmalavičius et al., 2007). Thus in the last 30 years, the rates of the Baltic Sea coastal abrasion have increased more than tenfold (Žilinskas, 2008).

\subsection{Compilation results on sustainable development and its indicators}

Modern society is not just about advanced technology and natural resources, but also faces the global challenges in the serious problems like global warming, decreasing biodiversity, etc. Concept of sustainable development has been designed to avoid major environmental problems and at the same time ensure the economic growth and human development opportunities for alternative (Abolina, Klavinš, 2000).

In scientific literature there is a wide variety of approaches to sustainable development. The authors from different countries have analyzed various aspects of sustainable development, what shows that its becoming a relevant interdisciplinary problem of nowadays (Table 1). 
Table 1. Definition of sustainable development

\begin{tabular}{|c|c|}
\hline Author & Definition \\
\hline Brundtland, 1987 & $\begin{array}{l}\text { Sustainability - this is a development that meets the needs of the modern world, without } \\
\text { risk of future generations to meet their own needs. Sustainable development of the concept } \\
\text { of the limits - not absolute limits but limitations apply existing technology and social } \\
\text { organization of the state of environmental resources and the ability to absorb the effects of } \\
\text { human activity }\end{array}$ \\
\hline $\begin{array}{l}\text { Rio Declaration on } \\
\text { Environment and } \\
\text { Development, } 1992 \\
\end{array}$ & $\begin{array}{l}\text { Sustainable development - a long-term continuous development of society, which aims to } \\
\text { meet human need in this time in the rational use and renewal of natural resources in the } \\
\text { future, while preserving the Earth for future generations }\end{array}$ \\
\hline $\begin{array}{l}\text { Goodland and Ledec, } \\
1987\end{array}$ & $\begin{array}{l}\text { Described the development as a stable economic transformation (development), optimizing } \\
\text { the economic effects and social benefits received now, without compromising ability to } \\
\text { obtain these benefits in the future }\end{array}$ \\
\hline $\begin{array}{l}\text { Čiegis, Petkevičiūtè, } \\
2008\end{array}$ & $\begin{array}{l}\text { Sustainable development - a better today and the quality of life for future generations. It } \\
\text { is an advanced vision for bringing economic development, environmental protection and } \\
\text { social justice }\end{array}$ \\
\hline Pužulis, 2010 & $\begin{array}{l}\text { Sustainable development must be understood in the light of social, psychological and } \\
\text { environmental indicators }\end{array}$ \\
\hline $\begin{array}{l}\text { Petkevičiūtè, } \\
\text { Svirskaitė, } 2001\end{array}$ & $\begin{array}{l}\text { Sustainable development can be understood as the process of economic expansion and the } \\
\text { structural changes that help to expand the human potential }\end{array}$ \\
\hline Briška, Rungule, 2011 & $\begin{array}{l}\text { This is the relationship between people and the environment and responsibility between the } \\
\text { present and future generations }\end{array}$ \\
\hline $\begin{array}{l}\text { Conway and Barbier, } \\
1990\end{array}$ & $\begin{array}{l}\text { Argue that economic sustainability is the ability to maintain productivity (and agricultural } \\
\text { assets and planted in the country in general) }\end{array}$ \\
\hline Stanaitis, 2006 & $\begin{array}{l}\text { The primary principle, that production must grow faster than the use of natural resources, } \\
\text { and the irregularities in nature does not have to exceed the permissible limits was worked } \\
\text { out }\end{array}$ \\
\hline
\end{tabular}

Source: based on Čiegis, Ramanauskienė, Martinkus, 2009, and author's ${ }^{1}$ compilation

In 1992, in Rios de Janeiro (Brazil), world leaders meeting devoted to environmental problems, the idea of sustainable development (or balanced development) has emerged

first. Then the idea was validated as the most important long-term strategy for development of the society. The need for compromise between environmental, economic and social goals of society, the need for a balanced long-term development strategy was understood.

To sum up the definitions of various authors, it can be said that sustainable development is an ongoing long-term goal which can't be achieved once and for all. Different countries and regions by the objectives of sustainable development can be very different, because of differences in the economic and cultural development. Sustainable development aims to ensure good living conditions not only for present but also for future generations maintaining compromise between environmental, social and economic goals of society.

The existing different approaches to sustainable development lead to the different priorities in different countries, where each of sustainable development system provides an efficient implementation of the maximum sustainable development in selected areas.

In order to determine the progress of sustainable development, the methodology was worked out with selected sets of indicators reflecting the sustainable development (Table 2). 
Table 2. The set of indicators for sustainable development assessment

\begin{tabular}{|l|l|}
\hline \multicolumn{2}{|c|}{ ECONOMIC INDICATORS } \\
\hline GDP per capita & Energy intensity measured by GDP \\
\hline Labor productivity per person employed & Renewable energy intake, percentage of GDP \\
\hline Final energy consumption & $\begin{array}{l}\text { Household expenditure municipal contribution (average farm } \\
\text { income per cent.) }\end{array}$ \\
\hline Inflation & Current account balance as a percentage of GDP \\
\hline Foreign direct investment as a percentage of GDP & Public debt (percentage of GDP) \\
\hline \multicolumn{2}{|c|}{ SOCIAL INDICATORS } \\
\hline Unemployment rate in percent & $\begin{array}{l}\text { The population at risk of poverty, percent. of the total } \\
\text { population }\end{array}$ \\
\hline Population, thousands & Registered criminal activity \\
\hline Life expectancy at birth & R \& D expenditure, percentage of GDP \\
\hline $\begin{array}{l}\text { Mortality from malignant neoplasms per 100 000 } \\
\text { inhabitants }\end{array}$ & Expenditure on social protection as a percentage of GDP \\
\hline $\begin{array}{l}\text { The natural population growth rate per 1,000 } \\
\text { population }\end{array}$ & \\
\hline \multicolumn{1}{|c|}{ ENVIRONMENTAL INDICATORS } \\
\hline Forest area per capita, ha & Air pollution, t \\
\hline Greenhouse gas emissions, million tonnes CO 2 & Household waste, kg1 capita \\
\hline People living in coastal parts & Urbanized areas \\
\hline Arable land area & The use of pesticides \\
\hline Felling intensity & \\
\hline
\end{tabular}

Source: made on the basis of information published by Eurostat and the UNCSD

\subsection{Scheme of assessment of sustainability of sea shore region development}

Different specialists are thinking how to improve the sets of indicators, which would better serve each concrete region or area. Sets of indicators may vary in compactness and complexity of the data. Different approaches to sustainable development indicators is a logical result, it allows to create not only a new set of indicators, but also to improve the old ones (OURCOAST - ICZM in Europe, 2011). That is why in this research we also focused on the set of sustainable development indicators, that could better reflect the current problems occurring in the sea shore region of Lithuania and Latvia with not high density of population round the year, but with several times increasing number of visitors and their load during summer season, certain restrictions of economic activities, intensity of erosional processes, etc. As sustainable development is consistently pursued goal should be ways to measure, how to get him approaching, what progress. Economic efficiency does not guarantee environmental and social sustainability through the use of economic indicators do not reflect the ecological and social sustainability. Sustainable development requires the evaluation of an integrated approach to the world, a set of indicators that evaluate and separate part of the system studied and the relationship between them (Čiegis, Zeleniūtè, 2008: 45). Thus we elaborated the scheme with most related steps towards the sustainability assessment in our studied region particularly (Fig. 4). For example, the environmental problems are important to be solved as friendlier as possible in the sea shore region, because the environment directly services human needs for recreation. The erosion is one of the most important natural phenomena which is necessary to be controlled and managed properly (Žilinskas, 2008; Pužulis, 2010; Jarmalavičius et. al., 2007), that is why it is included in our scheme. And the forested areas as well as ecologically managed land are of particular importance in the coasts preserving landscape and species diversity. From the economic indicators, the tourism as an perspective activity with all related 
infrastructure is desirable to be strengthened. Also other small and medium size business activities, providing different services, are necessary to be developed here.

From social indicators, all related to activity of human resources were included in the scheme.

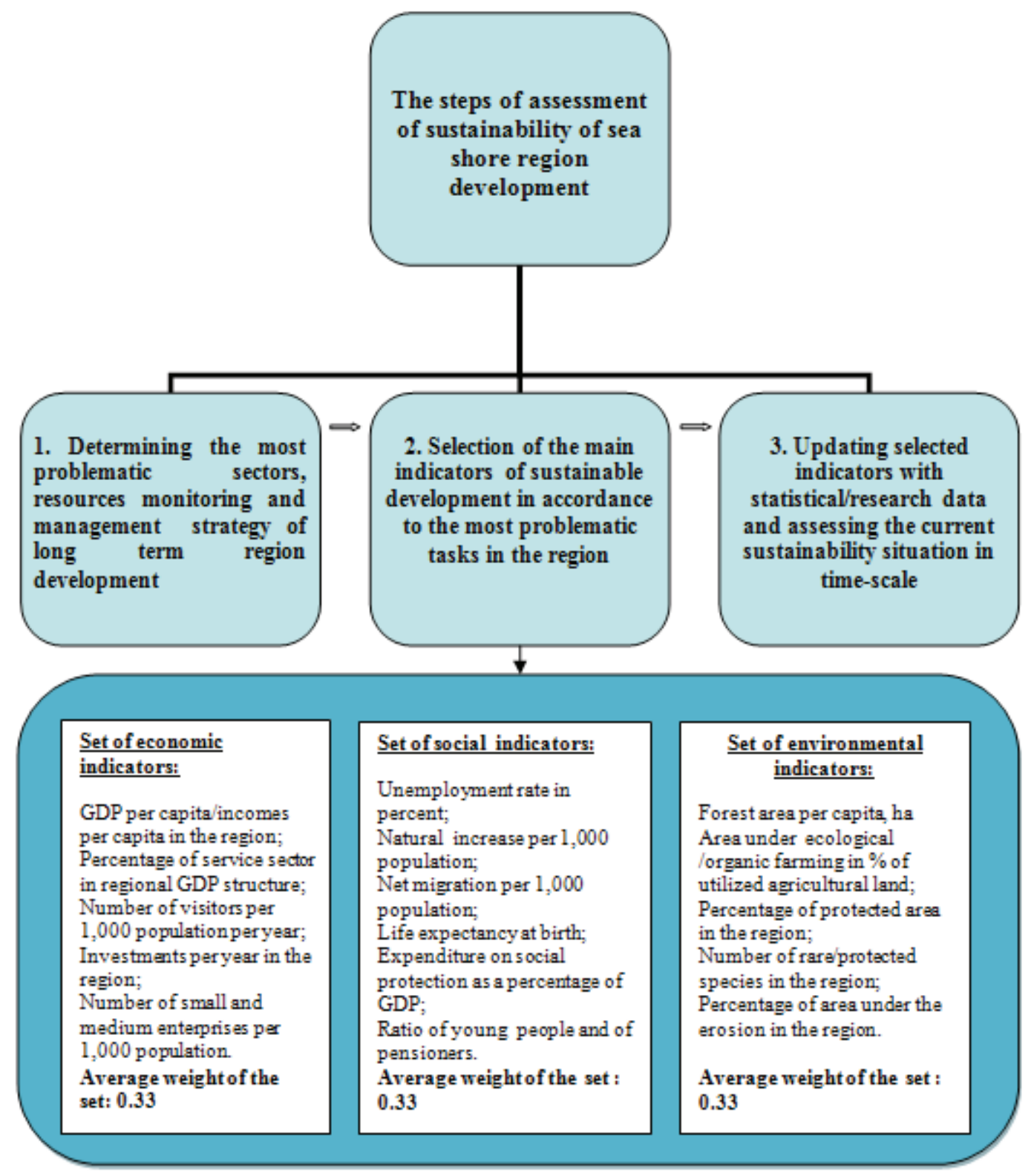

Figure 4. Scheme of assessment of sustainability of sea shore region development with selected indicators and their average weight.

Source: Worked out by the authors using Čiegis et al., 2010

All indicators are different, but the grading system in our scheme is the same, following the findings of Čiegis et al. (2010). The equal weight of each set of indicators makes possible to charge them as equally important. This scheme will be applied for estimation of degree of sustainability development in four Latvian and four Lithuanian sea shore municipalities during the period of the early country's membership in EU and in the recent years.

The first rule of the sustainable seaside resort development in the beginning of the 21 st century requires leaving the beach void of any permanent constructions in order to ensure the stability of the beach and its resilience to the wave action (Povilanskas, 2010-2011). However, the capacities and means for simultaneous 
management of the whole Lithuanian coastal zone are insufficient. Moreover, as practice has shown, much time is wasted on implementation of legal requirements (coordination of coastal management measures with various institutions, organization of tenders for concrete works, etc.). The following priority sectors were distinguished in the mainland coast of Lithuania: Palanga recreational zone (between Kunigiškès and Birute Mount and between the "Auska" villa and Coastal Regional park), Klaipeda recreational zone (between Giruliai and the technogenic zone of Klaipeda port), and coastal sector between the Šventoji port and the Latvian border. The following recreational zones of the Curonian Spit coast were classified as the priority ones: Smiltynè, Juodkrante, Pervalka, Preila, Nida, and the coastal zone of Kopgalis. The overall length of the recommended priority zones would be $32.5 \mathrm{~km}$, which would constitute $35.9 \%$ of the total length of the Lithuanian sea coast: $17.2 \mathrm{~km}$ of the mainland coast and 15.3 of the Curonian Spit coast (Žilinskas, 2008; Kavaliauskas, 2010).

In Latvia there has been no specific development policy for coastal areas: the existing policy goals and documents are related to environment protection. There have been a number of projects in Latvia that focus on preparing suggestions for integrated development and its supervision, but their further practical implementation has been limited. Considering the existing practice, there is a need to develop a coastal area development document of a national level, which had force of law and corresponding implementation and supervision instruments (Pužulis, 2010). Also it is important to know how are planning to develop their business micro, small and medium enterprises in the sea shore region. The survey of 150 top managers of micro and small business enterprises in Klaipeda region and in Latvia, Kurzeme region in 2011 fulfilled by the joint research of Klaipeda University and Liepaja University, has revealed, that most of economic activities are taking place in services and the trade, $33.5 \%$ and $23.5 \%$ respectively. Since the cooperation by forming horizontal networks is one of the main aspects of doing successful business in a globalised world, cooperation between organizations is one of stimulating factors of their development, and this could lead to the improvement of overall economic and social situation in the region (Šimanskienè et al., 2012). Such a survey has to be repeated after few years again.

\section{Conclusions}

To sum up the definitions of various authors on the sustainable development definition, it can be said that sustainable development is the development based on harmony and balance within Nature-Human system with clear responsibility of humans for their activities. Sustainable development - it is always a compromise between human needs and activities and the processes in the natural environment, and this is an ongoing long-term goal which can't be achieved once and for all.

Each region is unique, with its own natural and human resources, development problems and priorities that is why it's important for the assessment of region's development sustainability, to work out the most relevant research methodic/scheme.

All the selected indicators of sustainable development are different, but the grading system in the scheme we prepared is the same, with equal weight of each set of indicators $(0.33)$ which makes possible to charge them as equally important. This scheme will be applied for estimation of degree of sustainability development in four Latvian and four Lithuanian sea shore municipalities during the period of the early country's membership in EU and in the recent years.

\section{References}

Ābolina, K., Klavins, M. (2000). Indicators of Sustainable Development as Signals of the Development of Society. In: A. Krauklis (ed). Living with Diversity in Latvia. Folia Geographica. Research papers of the Latvian Geographical Society, Vol. 8, p. 15-24. Riga: Latvian Geographical Society.

Berkes, F., Colding, J., Folke, C. (eds). (2003). Navigating Social-Ecological Systems, Building Resilience for Complexity and Change. New York: Cambridge University Press, 393 p. 
Berkes, F., Folke, C. (1998). Linking Social and Ecological Systems, Management Practices and Social Mechanisms for Building Resilience. New York: Cambridge University Press, 459 p.

Bite, L., Makovskis, K. (2011). Thermal energy potentially to be obtained from the energy wood in final fellings and thinnings of Latvia. Management theory and studies for rural business and infrastructure development, Vol. 3 (27), p. 57. Research papers.

Bučienè, A., Beržanskis, A. (2011). Problems of the development of sustainable forestry and maintaining soil fertility in Lithuanian sea-shore region. 3rd International Symposium on Environmental Management. Towards Sustainable Technologies. Zagreb, Croatia, University of Zagreb, p. 50-57.

Bučienè, A. (2012). The shrinking rate of utilised agricultural land and its components in the Baltic sea region countries. Region Formation \& Development Studies, Vol. 6, Issue 1, p. 6-14.

Burgis, D., Čiegis, R. (2012). The problems of Lithuanian landscape in the context of sustainable development. Regional formation and development Studies, No. 1 (6), p. 47-56.

Carlsson, L., Berkes, F. (2003). Co-management Across Levels of Organization: Concepts and Methodological Implications. Chiang Mai, Thailand, July 11-14, 2003.

Carlsson, L., Lazdinis, M. (2004). Institutional Frameworks for Sustainability? A Comparative Analysis of the Forest Sectors of Russia and the Baltic States. Ambio, Vol. 33, No. 6, p. 402-419. Royal Swedish Academy of Sciences. Website: http://www.ambio.kva.se

Cash, D. W., Moser, S. C. (2000). Linking global and local scales: Designing dynamic assessment and management processes. Global Environmental Change, Vol. 10 (2), p. 109-120.

Čiegis, R., Ramanauskienè, J., Martinkus, B. (2009). The concept of sustainable development and its use of sustainability scenarios.

Čiegis, R., Ramanauskienė, J., Šimanskienè, L. (2010). Lietuvos regionu darnaus vystymosi vertinimas. Klaipėda: KU l-kla, $124 \mathrm{p}$.

Čiegis, R., Zeleniūtè, R. (2008). Ekonomikos plètra darnaus vystymosi aspektu. Taikomoji ekonomika: sisteminiai tyrimai, Nr. 2/2.

Eurostat. (2013). Website: http://epp.eurostat.ec.europa.eu/portal/page/portal/eurostat/home

Gadal, S., Lekavičiūtè, J. (2012). Remote sensing processing consequences of political and economical changes on Klaipeda county forests (1986-2005). Regional formation and development Studies, No. 1 (6), p. 37-46.

Jarmalavičius, D., Žilinskas, G., Dubra, V. (2007). Pattern of long-term seasonal sea level fluctuations in the Baltic Sea near the Lithuanian coast. Baltica, Vol. 20 (1/2), p. 28-34.

Latvia statistical department. (2013). Website: http://www.csb.gov.lv/

Jüros krantú apsaugos ir naudojimo nuostatai. Lietuvos Respublikos aplinkos ministro įsakymas, $2000 \mathrm{~m}$. vasario $24 \mathrm{~d}$. Nr. 73. Vilnius: Lietuvos Respublikos aplinkos ministerija.

Lithuanian statistical department. (2013). Website: http://www.stat.gov.lt/

Kavaliauskas, P. (2010). Sustainable and balanced development of Lithuanian Curonian Spit and Neringa municipality: planning and political aspects. Technological and economic development of economy, Vol. 16 (1), p. 58-74.

Lapinskis, J. (2005). Long-term fluctuations in the volume of beach and foredune deposits along the coast of Latvia. Baltica, Vol. 18 (1), p. 30-43.

Lazdinis, M. (2002). Facilitating sustainable forest development: Comparative analysis of post-soviet forest politics in the Baltic states. PhD Thesis, Southern Illinois University, Carbondale, IL, USA, 388 p.

Meža nozare Latvijā. (2009). Website: http://www.zm.gov.lv/doc_upl/Meza_nozare_Latvija_2009.pdf [22.12.2012].

National report of Latvia on the Baltic Green Belt [the coastal zone]. (2012). Study on possibilities and hindrances for sustainable development of national coastal regions. Riga.

OURCOAST - ICZM in Europe. (2011). Comparative Analyses of the OURCOAST cases (final draft) 8 June. Website: www.download(1).pdf [20.04.2012].

Povilanskas, R. (2010-2011). Principles and rules of sustainable resort development. Annales Geographicae, Vol. 4344, p. 76-84.

Programme of Lithuanian Baltic Sea coastal management for 2008-2013. (2007). Report, Institute Geology and Geography, Vilnius, 95 p. (In Lithuanian).

Pužulis, A. (2010). The Baltic Coastal Area Management Issues in Latvia. TILTAI. Scientific journal of Klaipéda University, Nr. 1, p. 89-100.

SH7 Red-listed shore habitat types. Website: http://www.biodiversity.fi/en/indicators/shores/sh7-red-listed-habitats

Ruskule, A., Veidemene, K. (2011). Developing a Pilot Maritime Spatial Plan of the Western Coast of Latvia. Environmental forum Latvia, p. 10.

Spiriajevas, E. (2012). Hindrances and suggestions for sustainable development of Lithuanian coastal strip (zone). Regional formation and development Studies, No. 1 (6), p. 125-136. 
Šimanskienè, L., Burgis, D., Līduma, D., Zeltina, M. (2012). Verslo bendradarbiavimas Klaipèdos regiono ir Latvijos pasienyje. Regional formation and development Studies, No. 1 (6), p. 137-146.

Veidemane, K. (2011). The Impact of Driving Forces and Protection Policies on Future Coastal Landscapes: A Case Study of Latvia. In: G. Schernewski, J. Hofstede, T. Neumann (eds). Global Change and Baltic Coastal Zones, Coastal Research Library-Series, Springer, Dordrecht, Vol. 1, p. 193-210.

Veteikis, D., Šabanovas, S., Jankauskaite, M. (2011). Landscape structure changes on the coastal plain of Lithuania during 1998-2009. Baltica, Vol. 24 (2), p. 107-116. Vilnius.

Walter, C., Stützel, H. (2009). A New Method for Assessing the Sustainability of Land-Use Systems (I): Identifying the Relevant Issues. Ecological Economics, Vol. 68, p. 1275-1287.

Žilinskas, G. (2008). Distinguishing priority sectors for the Lithuanian Baltic Sea coastal management. Baltica, Vol. 21 (1-2), p. 85-94. Vilnius.

\title{
PAJÜRIO REGIONO TAUSOJIMO IR JO IVERTINIMO PROBLEMATIKA
}

\author{
Kristina Ramanauskaité, Angelija BuČIEnĖ \\ Klaipėdos universitetas (Lietuva)
}

\section{Santrauka}

Jūros pakrantės regionai, arba zonos, pasaulyje vertinami kaip išskirtinès svarbos teritorijos, kur sutelktas didžiausias gamtos ir žmogiškujų išteklių potencialas. Todèl jų plètra turètų būti tausojamojo pobūdžio, darni, paremta potencialo reprodukcija, optimaliu plètros aspektų santykiu ir vienodai nukreipta į žmonių gyvenimo lygio bei kokybės gerinima, gamtinès aplinkos unikalumo išsaugojimą.

Šio tyrimo tikslas - išanalizuoti mokslinę ir metodinę tausojančios regionų plètros teoriją ir praktinius žingsnius nagrinejjančius straipsnius bei kitus šaltinius, siekiant parengti Lietuvos ir Latvijos pajūrio regiono plètros būklès analizei pritaikytą tyrimų schemą. Darbe sprendžiami šie uždaviniai: 1) mokslinès literatūros šaltinių analizé; 2) tyrimų metodikos / schemos rengimas.

Tyrimo metodai: mokslinès literatūros analizè, loginės analizės principų (tokių kaip palyginimas, abstrahavimas, apibendrinimas) taikymas, metodinių darbų analizè. ArcGis 10.1 programa naudota rengiant regiono žemèlapi.

Pristatomas tiriamas pajūrio regionas, kuri sudaro 4-ios Lietuvos savivaldybès ir 4-ios Latvijos savivaldybės pajūryje: Neringos miesto, Klaipėdos miesto ir rajono, Palangos miesto ir Kretingos rajono savivaldybès, Liepojos miesto ir rajono, Ventspilio miesto ir rajono, Talsi rajono savivaldybès. Aptariami šio regiono svarbiausi gamtos ir žmogiškieji ištekliai, nurodomos prioritetinės pagal priimtas strategines plètros kryptis veiklos bei esminiai aplinkosauginès politikos aspektai.

Ivairūs tausojančios plètros tyrèjai ir analitikai skirtingai vertina patị tausojimo ar darnumo apibrèžimą. Darbe pateikiami sugrupuoti pagrindiniu šia tema rašančių ivairiu šalių autorių tausojančios pletros apibrežzimai. Apibendrintai galima teigti, kad tausojanti plètra yra tokia, kuri plètojama darniai, nepažeidžiant gamtos procesų. Tai nėra galutinis apibrèžtas rezultatas, o nuolatinis kompromisas tarp žmogaus ir gamtos, kai žmogus prisiima atsakomybę už savo veiklą.

Analizuojami ir pateikiami sugrupuoti pagrindiniai ekonominiai, socialiniai ir gamtiniai rodikliai, ivairiu autorių bei Eurostat ir Jungtinių Tautų informacinėje duomenų bazejje rekomenduojami taikyti darnios plètros analizei. Autorès pateikia savo sudarytą metodinių tyrimų schemą, papildytą Lietuvos ir Latvijos pajūrio regionui pritaikytu svarbių plètros rodiklių sąrašu su jų svorio koeficientais, kurie visoms trims rodiklių grupèms yra vienodi (vidutiniškai 0,33). Ši metodika bus tikrinama praktiškai įvertinant tausojančios plètros būklę kiekvienoje iš 8 tiriamų savivaldybių laikotarpiu nuo įstojimo į ES pradžios iki šių metų.

PAGRINDINIAI ŽODŽIAI: tausojimas, ¿̇vertinimas, pajūrio regionas.

JEL KLASIFIKACIJA: Q01,Q56. 